\title{
Estimasi Gradien Temperatur Menggunakan Metode Geomagnet Pada Daerah Panasbumi Di Desa Sapoo Kecamatan Kulawi
}

\author{
(Temperature Gradient Estimation Using Geomagnetic Method \\ In Geothermal Area Of Sapoo In Subdistrict Of Kulawi)
}

\author{
Nurarafah $^{*}$, Rustan Efendi, Sandra \\ Program Studi Fisika Jurusan Fisika FMIPA, Universitas Tadulako, Palu, Indonesia
}

\begin{abstract}
The research using spectrum analysis on the data in the geomagnetic has been conducting in Sapoo Geothermal Field, Sigi. This study aimed to obtain the estimation of Curie temperature gradient in the geothermal area. The study stages include measuring magnetic anomalies; taking data acquisition, making corrections of IGRF and corrections of daily variations, and creating a contour map of the anomaly. Based on the contour map of the magnetic field of the anomalies qualitative interpretation, it obtained the value of a high magnetic anomaly of (340 nT), and a low magnetic anomaly of (-20 nT). The technique used is the spectral analysis techniques to obtain depth and to determine the temperature and flow of geothermal gradient in the study area. The average value obtained by the to depth, middle depth, and basalt depth are $1,267 \mathrm{~m}, 2,161 \mathrm{~m}$, and $3054.5 \mathrm{~m}$, respectively.. The temperature gradient value of the track $\mathrm{A}, \mathrm{B}, \mathrm{C}$ and track $\mathrm{D}$ are $0.19748042{ }^{\circ} \mathrm{C} / \mathrm{m}, 0.21577381^{\circ} \mathrm{C} / \mathrm{m}$. $0.18709677^{\circ} \mathrm{C} / \mathrm{m}$, and $0.16604638^{\circ} \mathrm{C} / \mathrm{m}$, respectively.
\end{abstract} \section{Gradient}

Keywords: magnetic anomalies, Spectrum Analysis, Depth Curie Temperature

\begin{abstract}
ABSTRAK
Penelitian menggunakan analisis spektrum pada data geomagnet telah dilakukan di Lapangan Panasbumi Sapoo, Kabupaten Sigi. Penelitian ini bertujuan untuk memperoleh estimasi gradien temperatur Curie pada daerah panasbumi tersebut. Tahapan pengukuran anomali magnetik meliputi; akuisisi data lapangan, melakukan koreksi IGRF dan koreksi variasi harian, dan kemudian membuat peta kontur anomali. Berdasarkan peta kontur anomali medan magnet hasil interpretasi kualitatif, diperoleh nilai anomali magnet tinggi sebesar (340 n), dan anomali magnet rendah sebesar(-20 nT). Teknik yang digunakan adalah teknik analisis spektrum untuk memperoleh kedalaman dan untuk mengetahui gradien temperatur dan aliran panasbumi di daerah penelitian. Nilai rata-rata kedalaman yang diperoleh yaitu untuk kedalaman atas, kedalaman tengah, dan kedalaman basal adalah berturut-turut $1.267 \mathrm{~m}$, $2.161 \mathrm{~m}$, dan $3.054,5 \mathrm{~m}$. Nilai gradien temperatur masing-masing lintasan yaitu lintasan A, lintasan $\mathrm{B}$, lintasan $\mathrm{C}$, lintasan $\mathrm{D}$ adalah berturut-turut $0,19748042{ }^{\circ} \mathrm{C} / \mathrm{m}, 0,21577381{ }^{\circ} \mathrm{C} / \mathrm{m}$, $18709677^{\circ} \mathrm{C} / \mathrm{m}$ dan $0,16604638^{\circ} \mathrm{C} / \mathrm{m}$.
\end{abstract}

Kata Kunci: Anomali magnetik, Analisis Spektrum, Kedalaman Curie, Gradien Temperatu 


\section{LATAR BELAKANG}

Panasbumi merupakan salah satu sumber daya alam yang memiliki potensi sangat besar untuk dimanfaatkan sebagai salah satu sumber energi alternatif. Fakta menunjukkan bahwa Indonesia merupakan daerah yang berpotensi akan sumber daya alam, termasuk sumber daya panasbumi, dan salah satunya yang terdapat di Sulawesi Tengah yaitu di Desa Sapoo Kecamatan Kulawi Kabupaten Sigi (Minarto, 2007).

Sumber panasbumi yang berada di Desa Sapoo perlu diselidiki karena terdapat sumber mata air panas yang muncul di atas permukaan tanah yang dapat dikembangkan sebagai energi alternatif dimasa mendatang. Energi panasbumi adalah energi panas yang tersimpan dalam batuan di bawah permukaan bumi dan fluida yang terkandung di dalamnya, dan untuk memanfaatkan potensi panasbumi tersebut dengan optimal maka perlu dilakukan penyelidikan struktur perlapisan bawah permukaan dan estimasi gradien temperatur daerah panasbumi Desa Sapoo.

Metode geomagnet adalah salah satu metode yang dapat mengukur adanya potensi panasbumi. Dalam penelitian panasbumi, penggunaan metode geomagnet didasarkan pada perbedaan sifat kemagnetan batuan. Dimana batuan mengalami kenaikan temperatur Curie (Tc) maka batuan tersebut akan mengalami penurunan kemagnetan (demagnetisasi). Secara umum temperatur Curie akan lebih tinggi pada batuan yang mengandung titano-magnetik sebagai penyusun mineral magnetik, dapat dijadikan sebagai indikator untuk mendeteksi temperatur Curie pada kedalaman yang cukup besar (Blakely et al. 1995 dalam Syamsurijal, 2011).

Untuk mengetahui posisi kedalaman anomali yang disebabkan oleh sumber panasbumi digunakan salah satu teknik yaitu analisis spektrum. Teknik analisis spektrum ini telah dilakukan oleh beberapa peneliti, diantaranya Maden (2009) pada penetuan kedalaman titik Curie sumber panasbumi dengan analisis spektrum di Turki Tengah.

Dalam penelitian ini digunakan analisis spektrum untuk mengestimasi gradien temperatur yaitu untuk mengetahui perubahan temperatur terhadap kedalaman.

Panasbumi adalah panas dari dalam bumi yang terdesak ke permukaan bumi disebabkan oleh pergerakan bumi. Air hujan yang menyerap ke dalam bumi melalui celah-celah bumi ini membentuk cekungan air yang terkontaminasi panas yang kemudian naik ke permukaan dan dikeluarkan sebagai geyser, fumarol dan mata air panas (Moediyono, 2010).

Energi panasbumi adalah energi panas yang diekstraksi dari panas yang 
tersimpan di dalam bumi. Secara umum perubahan kenaikan temperatur terhadap kedalaman di kerak bumi adalah sekitar $30^{\circ} \mathrm{C} / \mathrm{km}$. Jika diasumsikan temperatur rata-rata permukaan bumi adalah $15^{\circ} \mathrm{C}$, maka di kedalaman $3 \mathrm{~km}$, temperaturnya akan mencapai $105^{\circ} \mathrm{C}$. Akan tetapi temperatur tersebut kurang menguntungkan dari sisi ekonomis untuk dimanfaatkan sebagai energi panasbumi.

Sistem panasbumi yang terdapat di daerah penelitian diduga akibat adanya bermacam-macam batuan seperti batuan sekis hijau, batuan granit genesis, batuan Sabak-Filit, coluvium, dan aluvium. Selain batuan terdapat pula Sesar Palu Koro yang merupakan sesar terbesar di Sulawesi Tengah. Pada umumnya mata air panas di Desa Sapoo termasuk ke dalam tipe air panas bikarbonat yang sebagian berupa "immature weters" seperti di daerah Sibalaya, Walatana, Limba dan Simoro. Sedangkan Pulu, Sapoo, Mapane dan Kaliburu berada di daerah "partial equilibrum”(Bakrun dkk., 2003).

Medan magnet bumi terdiri dari 3 bagian yaitu:

1. Medan Utama (main field) dapat didefinisikan sebagai medan rata-rata hasil pengukuran dalam jangka waktu yang cukup lama (Blakely, 1996).
2. Medan Luar (external field), berasal dari pengaruh luar bumi seperti pengaruh di atmosfer.

3. Medan Anomali Magnetik (magnetic anomaly) variasi medan magnetik yang terukur di permukaan merupakan target dari survei magnetik (anomali magnetik).

Menurut Telford

(1996),

kerentanan suatu benda magnetik untuk dimagnetisasi ditentukan oleh suseptibilitas kemagnetan atau $k$, yaitu:

$$
\mathrm{I}=k \mathrm{H}
$$

Dengan : $\quad I=$ Magnetisasi

$k=$ Suseptibilitas Batuan (SI)

$$
\mathrm{H}=\text { Medan Magnet }
$$

Harga $k$ pada batuan semakin besar apabila dalam batuan tersebut semakin banyak dijumpai mineral-mineral yang bersifat magnetik (Telford, 1996).

Hubungan suseptibilitas magnetik $(k)$, terhadap temperatur berdasarkan sifat magnetik bahan, yaitu (Rosanti, 2010) :

1. Ferromagnetik adalah benda magnetik yang mudah termagnetisasi mempunyai nilai $k$ positif dan besar, yaitu $k>0$, dan $k>1$. Pada saat $\mathrm{T}<\mathrm{T}_{\mathrm{C}}=$ temperature Curie, maka daerah ini dikatakan daerah ferromagnetik. Ferromagnetik bergantung pada suhu, saat suhunya turun maka nilai $k$ akan bertambah, sedangkan pada saat temperature Curie 
maka nilai $k$ akan hilang. Ferromagnetik dibedakan menjadi 2, yaitu:

a. Ferrimagnetik adalah benda magnetik yang mempunyai nilai $\mathrm{k}$ yang besar tergantung temperature, tetapi jauh lebih rendah dari bahan Ferromagnetik.

b. Antiferromagnetik adalah benda magnetik yang mempunyai nilai $\mathrm{k}$ sangat kecil yaitu mendekati nilai $\mathrm{k}$ pada benda paramagnetik. Antiferromagnetik bergantung pada suhu, nilai $\mathrm{k}$ akan naik pada saat kenaikan suhu dengan titik Curie, dan akan turun pada suhu tertentu.

2. Paramagnetik adalah benda magnetik yang mudah termagnetisasi mempunyai nilai $k$ kecil dan positif, yaitu $k>0$, dan $k \ll 1$. Pada saat $\mathrm{T}>$ $\mathrm{T}_{\mathrm{C}}$ maka daerah ini dikatakan daerah paramagnetik. Paramagnetik memiliki nilai $k$ berbanding terbalik terhadap suhu.

3. Diamagnetikadalah benda yang mempunyai nilaik kecil dan negatif, yaitu $k<0$. Semua bahan secara teoritis bersifat diamagnetik pada temperatur yang cukup tinggi.

Anomali magnetik menyebabkan perubahan dalam medan magnet total bumi dan dapat dituliskan sebagai:

$$
\mathrm{H}_{\mathrm{T}}=\mathrm{H}_{\mathrm{M}}+\mathrm{H}_{\mathrm{A}}
$$

Bila besar $\mathrm{H}_{\mathrm{A}} \ll \mathrm{H}_{\mathrm{T}}$ dan arah $\mathrm{H}_{\mathrm{A}}$ hampir sama dengan arah $\mathrm{H}_{\mathrm{T}}$ maka anomali magnetik totalnya adalah:

$$
\Delta \mathrm{H}_{\mathrm{A}}=\mathrm{H}_{\mathrm{T}}-\mathrm{H}_{\mathrm{M}}
$$

Keterangan :

$\mathrm{H}_{\mathrm{T}}=$ Medan Anomali Magnetik Total

$\mathrm{H}_{\mathrm{M}}=$ Medan Magnet Utama Bumi

$\mathrm{H}_{\mathrm{A}}=$ Medan Anomali Magnetik

Analisis spektrum adalah salah satu analisis harmonik yang digunakan untuk menganalisis fenomena osilator harmonik di alam. Tujuan dari analisis ini adalah untuk mendapatkan distribusi spektrum dari fenomena osilator harmonik dan untuk menunjukkan karakteristik statistiknya (Blakely, 1996).

Dalam penelitian ini digunakan hubungan metode magnetik dengan analisis spektrum untuk menyelidiki kedalaman panasbumi. Metode ini memberikan hubungan antara spektrum anomali magnetik dan kedalaman sumber magnet dalam domain frekuensi (Alimudin, 2008).

$$
\text { Curie Point Depth }
$$

(CPD) didefinisikan sebagai kedalaman temperatur Curie dimana mineral magnetik kehilangan sifat kemagnetannya. Temperatur Curie umumnya lebih tinggi pada batuan beku mafik dibanding batuan lainnya, akibat kadar titano-magnetik yang terkandung lebih besar. Kehadiran mineral magnetik seperti magnetite $\left(\mathrm{Fe}_{3} \mathrm{O}_{4}\right)$, 
ulvospine $\left(\mathrm{Fe}_{2} \mathrm{TiO}_{4}\right)$, hematite $\left(\mathrm{Fe}_{2} \mathrm{O}_{3}\right)$ dan lainnya sebagai mineral penyusun kerak bumi akan meningkatkan temperatur Curie sampai sekitar $580{ }^{\circ} \mathrm{C}$ (Blakely $1995 \mathrm{dkk}$ dalam Syamsurijal, 2011 ).

CPD secara langsung dipengaruhi oleh temperature batuan bawah permukaan akibat aktivitas tektonik. Batuan umumnya diklasifikasikan berdasarkan komposisi mineral, sifat kimia dan fisika berdasarkan tekstur, komposisi, susunan dan proses terbentuknya. Salah satu besaran fisis yang digunakan untuk klasifikasi batuan adalah sifat kemagnetan atau suseptibilitas (Milsom dalam Syamsurijal, 2011).

Dalam penelitian ini, sesuai dengan metode yang disajikan oleh Tanaka et al. (1999) untuk menghitung CPD, Blakely (1996) memperkenalkan power spektrum $\ln A=\ln B-|k| Z_{t}$

Okubo dkk dalam Essam (2011) mengusulkan sebuah algoritma untuk memperkirakan kedalaman basal dari data magnetik dengan mempertimbangkan teknik pemodelan 2D untuk penentuan kedalaman ke dasar untuk blok tunggal. Kemudian, algoritma memperkirakan kedalaman centroid $\left(\mathrm{Z}_{0}\right)$ dari skala kemiringan radial rata-rata power spektrum di bagian bilangan gelombang tinggi, dan kedalaman atas $\left(\mathrm{Z}_{\mathrm{t}}\right)$ dari kemiringan radial rata-rata power spektrum anomali magnetik dibagian bilangan gelombang rendah., seperti terlihat pada Gambar 1. Spektrum densitas daya dihitung untuk setiap lintasan. Keuntungan dari power spectrum 2D adalah kedalaman sumber yang mudah ditentukan dengan mengukur kemiringan grafik energi spektrum. Sebuah contoh dari kekuatan spektrum sub regional ditunjukkan pada Gambar 1. Teknik ini diterapkan pada frekuensi daya skala radial rata-rata untuk memperkirakan kedalaman centroid $\left(\mathrm{Z}_{0}\right)$. Akibatnya, kedalaman basal (Zb) kemudian diperoleh dengan menggunakan Persamaan 5. penelitian ini mengikuti prosedur Okubo et al (1985) dan memperkirakan kedalaman untuk sumber magnet atas dan pusat massa $\left(\mathrm{Z}_{\mathrm{t}}\right.$ dan $\mathrm{Z}_{0}$ ) ditunjukkan pada Gambar 1.

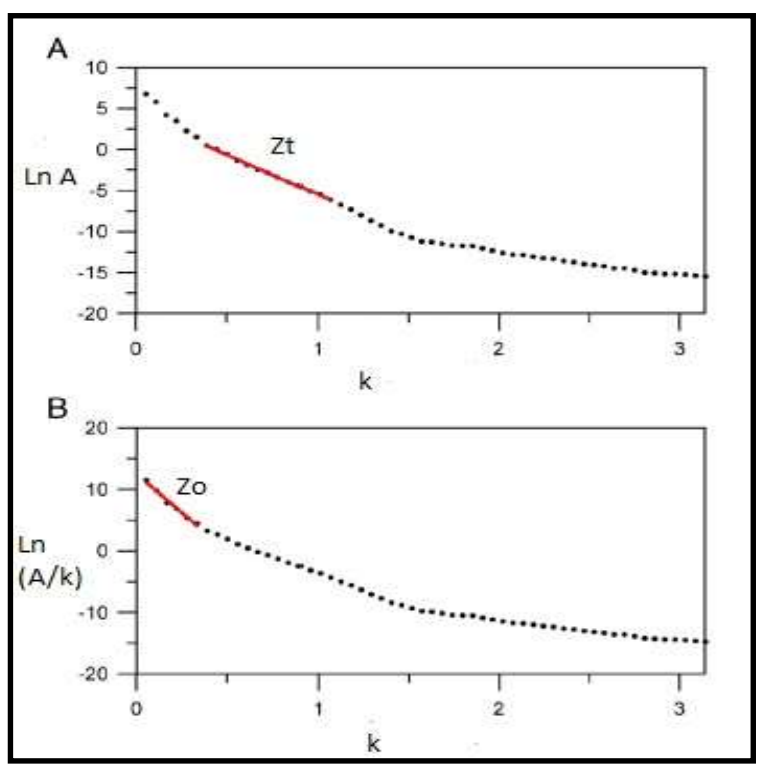

Gambar 1. Nilai $\mathrm{Zt}$, dan $\mathrm{Z}_{0}$ dalam kemiringan power spektrum (Essam Aboud dkk, 2011) 
Dari power spektrum anomali total, kemudian $\mathrm{Z}_{0}$ dapat diestimasi dengan Persamaan 4:

$$
\ln \left\{\frac{(\mathrm{A})}{(\mathrm{k})}\right\}=\ln D-|k| Z_{o}
$$

Dengan memasang garis lurus melalui bilangan gelombang tinggi dan rendah bagian dari power spektrum radial rata-rata dari $\ln A$ dan $k$, $\ln (\mathrm{A} / \mathrm{k})$ dan $k$, nilai $\mathrm{Z}_{\mathrm{t}}, \mathrm{Z}_{0}$ dapat diestimasi. Sinyal gelombang yang tertangkap pertama pada saat pengukuran merupakan sinyal gelombang untuk batas kedalaman sumber panasbumi $\left(\mathrm{Z}_{0}\right)$, dan selanjutnya merupakan sinyal gelombang untuk kedalaman atas. Oleh sebab itu plot grafik $Z_{0}$ di lakukan pada nilai bilangan gelombang awal dan $Z_{t}$ pada bilangan gelombang dibawahnya. Selanjutnya nilai $\mathrm{Z}_{\mathrm{b}}$ dapat diestimasi dengan Persamaan 6 (Essam et al., 2011)

$$
Z_{b}=2 Z_{o}-Z_{t}
$$

\section{Gradien} temperature perhitungannya dinyatakan oleh hukum Fourier dengan rumus

$$
\frac{d T}{d Z}=Z b
$$

Dalam persamaan ini, diasumsikan bahwa arah variasi suhu vertical dan gradien temperatur $\frac{d T}{d Z}$ adalah konstan (Tanaka, 1999).

Temperatur Curie $(\theta)$ diperoleh dari titik kedalaman Curie (Zb) dan gradient temperatur $\frac{d T}{d Z}$ menggunakan persamaan berikut :

$$
\theta=\left(\frac{d T}{d Z}\right)=\mathrm{Zb}
$$

\section{METODE PENELITIAN}

Penelitian dengan menggunakan Metode geomagnet dilakukan di Desa Sappo, Kecamatan Kulawi, Kabupaten Sigi, Provinsi Sulawesi Tengah (Gambar 2).

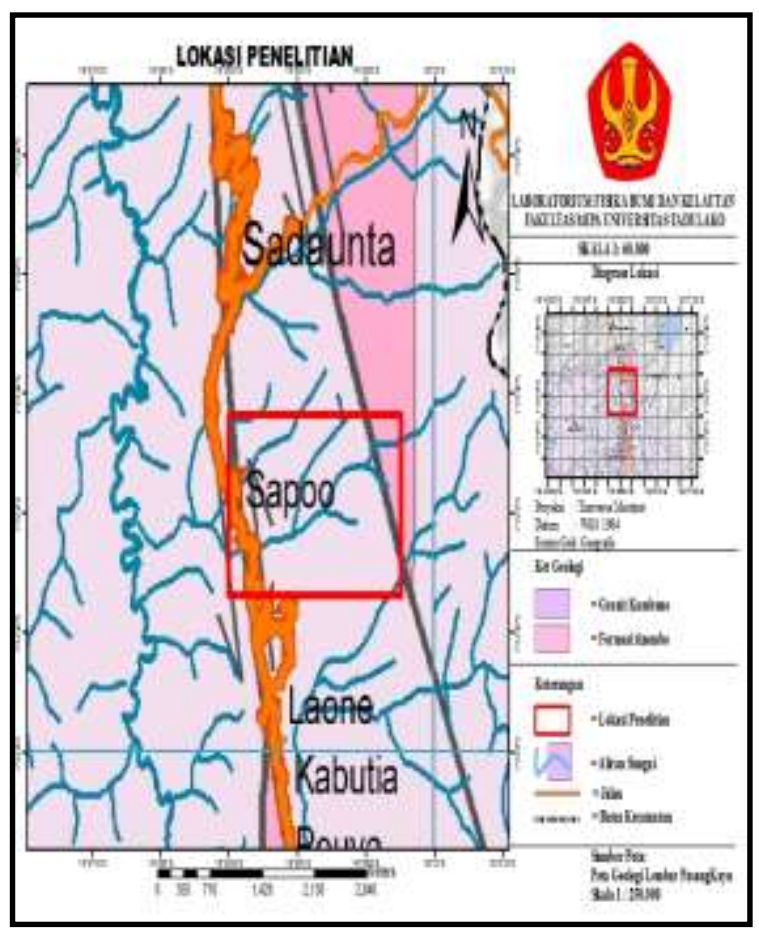

Gambar 2. Lokasi Penelitian

Pengambilan data menggunakan metode geomagnet beberapa peralatan sebagai berikut :

1. Dua set Proton Precision Magnetometer merek GS 19T. Alat ini digunakan di base dan di mobile.

2. Satu buah kompas geologi. 
3. Satu buah Global Positioning System $(G P S)$.

4. Jam untuk menunjukan waktu.

5. Alat tulis menulis untuk menulis data di lapangan.

Data yang diperoleh dari lapangan belum menunjukan nilai anomali magnetik total melainkan masih berupa data mentah hasil pengukuran karena pada data tersebut masih terdapat pengaruh dari dalam dan luar bumi. Data tersebut, kemudian diolah dengan menggunakan Program Software Surfer 10. Hasil yang diperoleh dari Program Surfer tersebut berupa peta kontur anomali.

Tahapan interpretasi pada penelitian ini, dilakukan secara kualitatif dan kuantitatif. Secara kualitatif dilakukan penganalisaan sebatas peta kontur anomali medan magnet total. Hasil yang diperoleh berupa lokasi benda yang menyebabkan timbulnya anomali.

Proses interpretasi data dilakukan dengam membuat beberapa lintasan pada lokasi penelitian yang sesuai dengan peta kontur anomali. Pada setiap lintasan dihitung kedalaman dari sumber magnetik menggunakan analisis spectrum. Berdasarkan kedalaman dan titik Curie maka akan diperoleh variasi gradient temperatur, dan selanjutnya melakukan interpretasi pada setiap lintasan untuk mengetahui gradien geothermal pada daerah tersebut.

\section{HASIL DAN PEMBAHASAN}

Berdasarkan hasil interpretasi pada peta kontur anomali medan magnet dibuat 4 lintasan yang melalui titik air panas, yang akan digunakan pada estimasi kedalaman sumber magnetik di bawah permukaan. Lintasan-lintasan tersebut dibuat miring untuk memudahkan dalam interpretasi data dan keakuratan data. Keempat lintasan tersebut memiliki arah miring utara-selatan dan barat-timur yang dapat dilihat pada Gambar 3.

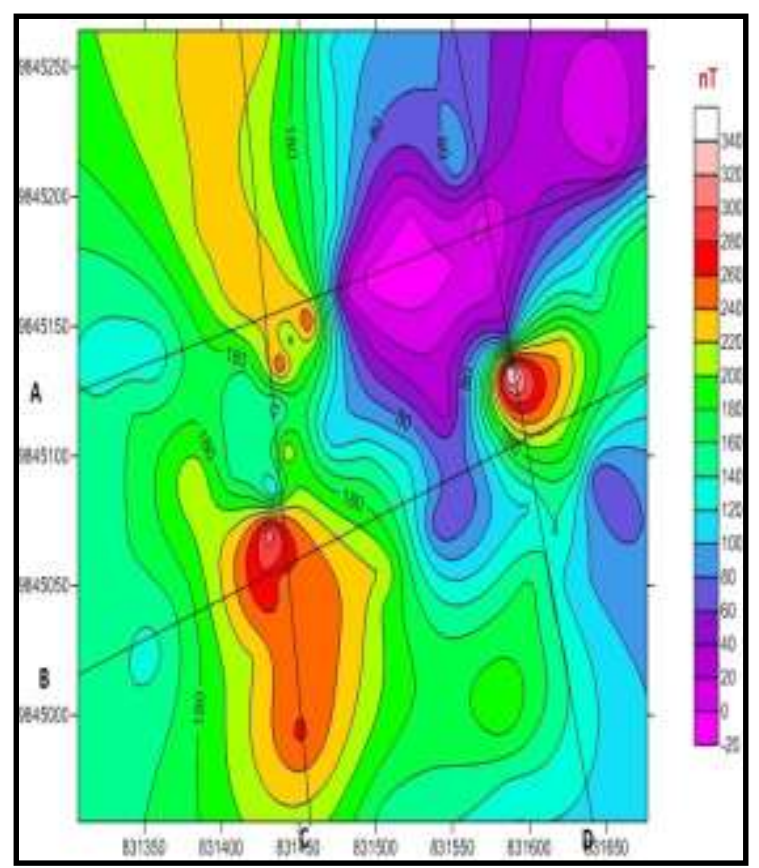

Gambar 3. Penampang Lintasan

Hasil titik-titik pengukuran geomagnet di desa Sapoo, nilai dari anomali magnetik pada Gambar 3 terdapat mata air panas yang ditandai dengan adanya sesar dan zona rekahan di daerah tersebut, yaitu sesar Palu Koro. Kemudian, nilai anomali 
yang terdapat pada Gambar 2 terlihat anomali magnet rendah (40nT s/d - $20 \mathrm{nT}$ ) melingkar di bagian timur ditafsirkan sebagai batuan yang bersifat nonmagnetik. Anomali tersebut diperkirakan berkaitan dengan batuan yang bersifat paramagnetik. Anomali magnet sedang (100 nT s/d 200 nT) ditafsirkan sebagai batuan bersifat nonmagnetik-magnetik (terdiri dari granit lapuk, sedimen klastika). Tersebar di semua bagian timur, barat, dan Utara. Anomali magnet rendah (210 nT s/d -340 nT) ditafsirkan sebagai batuan bersifat magnetik yang tersebar di timur bagian tengah, selatan dan utara.

Dalam melakukan pengolahan data dengan software Numeri, data yang dimasukan berupa nilai anomali dan jarak yang sudah diinterpolasi dengan $\Delta \mathrm{x}$ untuk setiap titik pengukuran yaitu 5 meter. Data tersebut dimasukkan dalam notepad, kemudian diolah dengan Numeri. Hasilnya berupa bilangan real-imajiner, dan frekuensi untuk setiap penampang. Nilai real-imajiner tersebut selanjutnya diakar kuadratkan dan diperoleh nilai amplitudonya (A). Setelah nilai amplitudo diperoleh, kemudian dibuat grafik estimasi kedalamannya, yaitu nilai ln A dan Ln A/k berdasarkan Persamaan 6, dimana kemiringan garis dari setiap garis tersebut adalah estimasi nilai kedalaman atas $\left(Z_{t}\right)$ dan kedalaman $\left(\mathrm{Z}_{0}\right)$ sumber anomali.
Gambar 4 menunjukkan estimasi kedalaman sumber panasbumi pada lintasan A. Kedalaman atas $\left(\mathrm{Z}_{\mathrm{t}}\right)$ diperoleh dengan menggunakan metode curve fitting yaitu dengan memotong dan mengambil garis lurus dari bilangan gelombang tinggi ke rendah, dan diperoleh nilai $Z_{t}$ yaitu 1.147 m, sedangkan untuk nilai kedalaman $\left(\mathrm{Z}_{0}\right)$ dengan mengambil garis lurus untuk grafik antara ln $\mathrm{A} / \mathrm{k}$ dengan $\mathrm{k}$ dari bilangan gelombang tinggi ke rendah. Nilai $\mathrm{Z}_{0}$ yang diperoleh dari grafik yaitu $2.043 \mathrm{~m}$. Kedalaman basal $\left(\mathrm{Z}_{\mathrm{b}}\right)$ atau biasa disebut Curie point depth (CPD) yang dihitung dengan menggunakan Persamaan 6 yaitu $2937 \mathrm{~m}$.

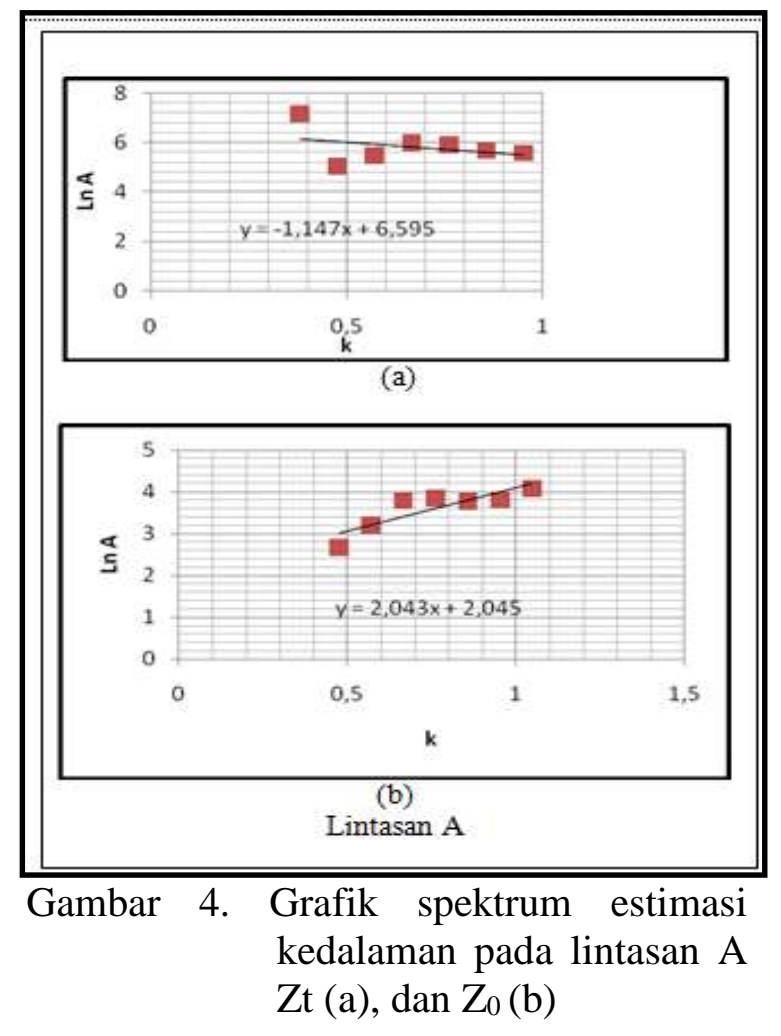

Gambar 5 merupakan grafik spektrum untuk estimasi kedalaman 
sumber panasbumi dari data magnetik dengan nilai $\mathrm{Z}_{\mathrm{t}}=1.330 \mathrm{~m}$ dan grafik spektrum kedalaman tengah menunjukan nilai $\mathrm{Z}_{\mathrm{o}}=2.009 \mathrm{~m}$. Sedangkan untuk $\mathrm{Z}_{\mathrm{b}}$ atau kedalaman basal yaitu $2.688 \mathrm{~m}$.

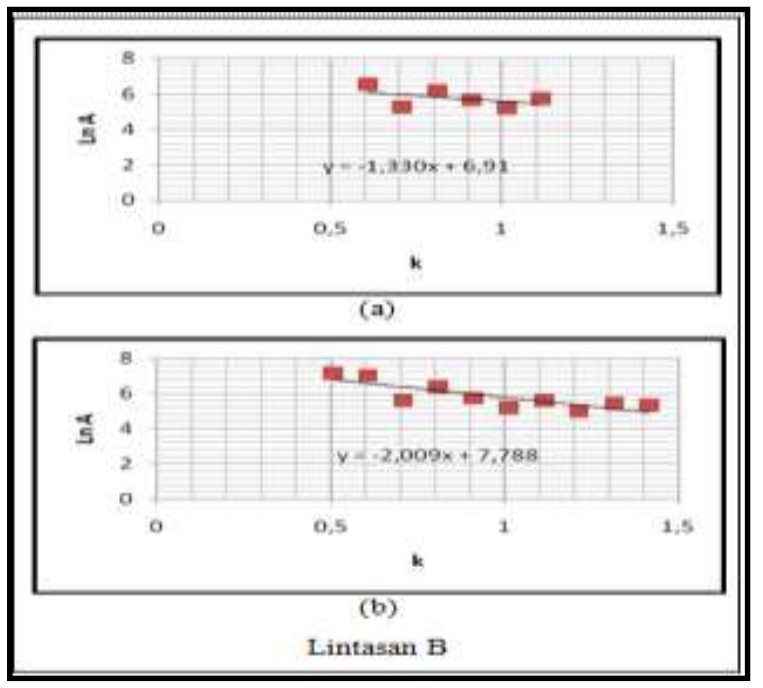

Gambar 5. Grafik spektrum estimasi kedalaman pada lintasan B $\mathrm{Zt}$ (a), dan $\mathrm{Z}_{0}$ (b)

Pada lintasan ini diperoleh nilai kedalaman yang agak rendah dibandingkan dengan lintasan A, C, dan D.

Gambar 6 menunjukkan grafik spektrum untuk estimasi kedalaman $\mathrm{Z}_{\mathrm{t}}$ yaitu $1.332 \mathrm{~m}$ dan nilai $\mathrm{Z}_{\mathrm{o}}$ sebesar 2.216 m. Sedangkan kedalaman basalnya $\mathrm{Z}_{\mathrm{b}}$ $3.100 \mathrm{~m}$

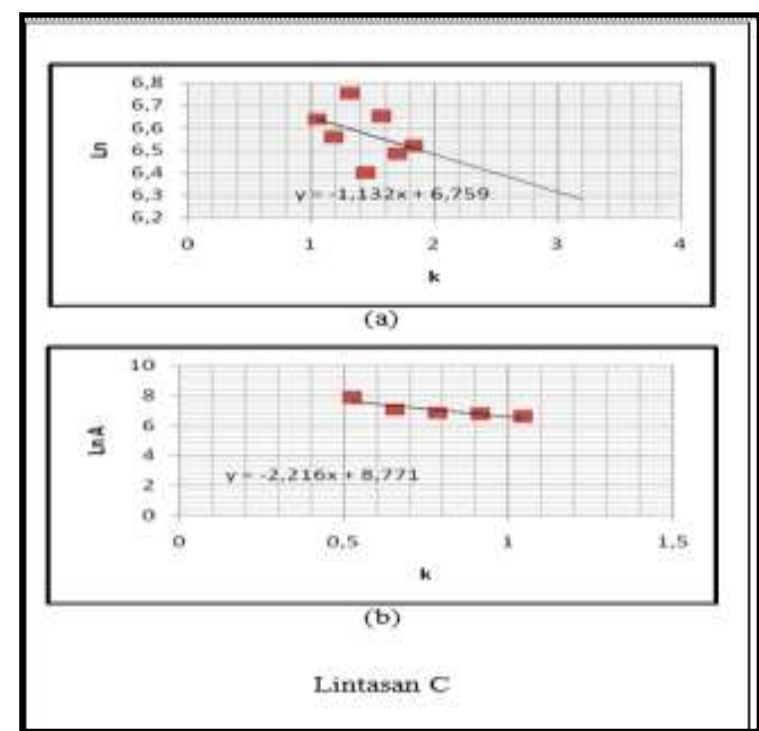

Gambar 6. Grafik spektrum estimasi kedalaman pada lintasan $\mathrm{C}$ $\mathrm{Zt}$ (a), dan $\mathrm{Z}_{0}$ (b)

Gambar 7 terlihat grafik estimasi kedalaman dengan nilai $\mathrm{Z}_{\mathrm{t}}=1.259 \mathrm{~m}$ dan $\mathrm{Z}_{0}=2.376 \mathrm{~m}$. Sedangkan untuk kedalaman basal $\left(Z_{b}\right)$ yaitu $3493 \mathrm{~m}$.

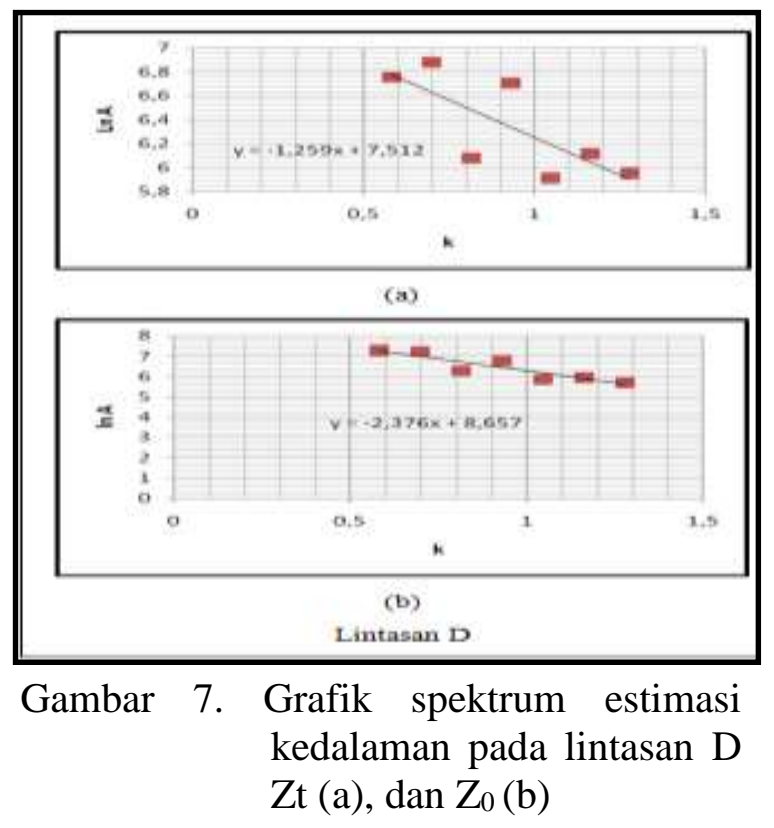

Selanjutnya melakukan estimasi dari masing-masing kedalaman sumber anomali pada setiap lintasan dan nilai dari gradien temperatur, nilai kedalaman yang 
diperoleh sebelumnya dapat dinyatakan mewakili dari setiap penampang. Nilai kedalaman dan gradien temperatur tersebut dapat dilihat pada Tabel 1 .

Tabel 1. Nilai kedalaman dan gradient temperatur dari masing-masing lintasan

\begin{tabular}{|c|c|c|c|c|c|c|}
\hline $\mathrm{No}$ & Intasen & $Z(m)$ & $z(m)$ & $z_{2}=\frac{22-Z}{(m)}$ & $\theta=5822^{2} \mathrm{C}$ & $\begin{array}{l}\text { Crabian } \\
\text { Temperatis } \\
(\mathrm{C} / \mathrm{m})\end{array}$ \\
\hline 1 & A & 1147 & $2: 43$ & 2937 & 5812.93 & $0,1978,44$ \\
\hline 2 & B & 1330 & 2069 & 2688 & 5622688 & 0,15738 \\
\hline 3 & C & 1332 & 2216 & 3.100 & 5803.10 & 0,1570967 \\
\hline \multirow[t]{2}{*}{4} & D & 1259 & 2376 & 3.493 & 28.3 .493 & 0,16604535 \\
\hline & Raturata & $125 ?$ & 2161 & 30545 & & 1,15159952 \\
\hline
\end{tabular}

Nilai kedalaman dan gradien temperatur disetiap lintasan yang dihitung menunjukkan bahwa nilai kedalaman batas atas $(\mathrm{Zt})$ berkisar antara $1.147 \mathrm{~m}$ sampai 1.332 m. Disisi lain kedalaman Centroid (Zo) sumber anomali berkisar antara 2.009 m sampai $2.376 \mathrm{~m}$. Kemudian nilai dari kedalaman bawah ( $\mathrm{Zb}$ ) yang setara ada dikisaran 2.688 m sampai 3.493 m cukup baik dengan apa yang diperoleh di kedalaman Centroid (Zo) dan disekitar batas atas.

Dengan menggunakan suhu titik Curie dari $580^{\circ} \mathrm{C}$, maka nilai gradien temperatur yaitu $0,166{ }^{\circ} \mathrm{C} / \mathrm{m}$ sampai 0,215 ${ }^{\circ} \mathrm{C} / \mathrm{m}$. Titik kedalaman temperatur Curie untuk lokasi panasbumi Sapoo yang diperoleh merupakan rata-rata nilai titik kedalaman Curie di setiap lintasan. Berarti penambahan kedalaman $1 \mathrm{~km}$, maka temperaturnya akan semakin meningkat sekitar $0,0001^{\circ} \mathrm{C}$.
Secara umum perubahan kenaikan temperatur terhadap kedalaman di kerak bumi adalah sekitar $30{ }^{\circ} \mathrm{C} / \mathrm{km}$. Jika diasumsikan temperatur rata-rata permukaan bumi adalah $15{ }^{\circ} \mathrm{C}$, maka di kedalaman $3 \mathrm{~km}$, temperaturnya akan mencapai $105{ }^{\circ} \mathrm{C}$. Temperatur tersebut kurang menguntungkan dari sisi ekonomis untuk dimanfaatkan sebagai sumber energi panasbumi (Suparno, 2009). Dapat dikatakan bahwa untuk daerah panasbumi Sapoo yang memiliki penambahan temperatur $0,0001{ }^{\circ} \mathrm{C} /$ setiap $1 \mathrm{~km}$, sangat jauh untuk dijadikan sebagai sumber energi

panasbumi

(Geothermal).Berdasarkan hasil penelitian yang telah dilakukan di Desa Sapoo, Kabupaten Sigi dengan menggunakan metode geomagnet dapat disimpulkan bahwa gradien temperatur untuk daerah panasbumi Sapoo adalah $0,019159935^{\circ} \mathrm{C} / \mathrm{m}$ yang berarti setiap penambahan kedalaman $1 \mathrm{~km}$ maka temperatur curie meningkat sebesar $0,0001^{\circ} \mathrm{C}$.

Untuk dapat mengetahui panasbumi di desa Sapoo secara detail, perlu dilakukan penelitian geofisika yang lainnya, sehingga hasil yang didapatkan dapat dibandingkan guna memperoleh hasil yang baik. 


\section{UCAPAN TERIMAKASIH}

Penulis mengucapkan terimakasih kepada teman-teman dan semua pihak yang terlibat, kepada Kepala Desa Sapoo Kecamatan Kulawi yang sudah membantu memfasilitasi penulis dengan memberikan izin dalam pengambilan data di lapangan.

\section{DAFTAR PUSTAKA}

Alimudin, 2008, Analisis Power Spektrum Data Gaya Berat Untuk Memperkirakan Kedalaman Bidang Batas Anomali LokalRegional, Prosiding Program Studi Geofisika, Universitas Lampung, Bandar Lampung.

Bakrun, H. S., Bangbang Sulaeman, Ario Mustang, dan Solaviah, 2003, Penyelidikan Terpadu Panasbumi Pulu Kabupaten Donggala, Kolokium Hasil Kegiatan Inventarisasi Sumber Daya Mineral, Bandung.

Blakely. R. J., 1996,. Potential Theory in Gravity and Magnetic anomalies due to two-dimensional structure. Geophysics 40, 993-1013

Essam, A., and Mahmoud, M, 2011, Curie depth map for Sinai Peninsula, Egypt deduced from the analisis of magnetic data, Jurnal Tectonophysics Vol. 506, Jeddah.

Minarto, 2007, Pemodelan Inversi Data Geolistrik Untuk Menentukan Struktur Perlapisan Bawah Permukaan Daerah Panasbumi Mataloko, Jurnal Geofisika, Surabaya.Moediyono, 2010, Pembangunan Pembangkit Listrik Tenaga Panas Bumi (PLTPB), Universitas Diponegoro, Semarang
Maden, N, 2009, Curie Point Depth from Spectral Analysis of Magnetic Data in Erciyes Stratovolcano, Jurnal Pure Appl. Geophys. Vol. Switzerland

Okubo, Y.J.R, 1985, Curie Point Depth of the island of kyush.u and surrounding areas, Japan Geophysic. Vol. 53

Rosanti, dan Farida, D. 2012, Korelasi antara Suseptibilitas Magnetik dengan Unsur Logam Berat pada Sekuensi Tanah di Pujon Malang. Skripsi: Universitas Negeri Malang.

Suparno, 2009, Energi panasbumi - A present to the Earth Edisi 1, Departemen Fisika FMIPA, Universitas Indonesia.

Syamsurijal, R, 2011. Penentuan Curie Point Depth Data Anomali Geomagnetik Dengan Menggunakan Analisis (Studi Kasus: Daerah Prospek Geothermal Segmen Gunung Rajabasa Lampung), Prosiding Seminar Nasional Sains \& Teknologi-IV, Lampung.

Tanaka, A.,Y, Okubo, O. Matsubayashi, 1999, Curie Point Depth Based on Spectrum Analysis of the Magnetic Anomaly data in East and Asia, Tectonophysics, Vol.306

Telford, W M, L.P. Geldart, and R.E. Sherriff , 1996, Applied Geophysics Second Edition, Cambridge University Press, Australia 